\title{
The origin of the extraordinary stability of mercury catalysts on the carbon support: the synergy effects between oxygen groups and defects revealed from a combined experimental and DFT study
}

\author{
Jian Li ${ }^{a}, \dagger$, Jiangtao Fan ${ }^{a, \dagger}$, Sajjad Ali ${ }^{b}$, Guojun Lan ${ }^{a}$, Haodong Tang a, Wenfeng Han a, Huazhang Liu a, \\ Bo Li ${ }^{b, \#, ~ Y i n g ~ L i ~ a, * ~}$ \\ a Institute of Industry Catalysis, Zhejiang University of Technology, Hangzhou 310014, Zhejiang, China \\ b Shenyang National Laboratory for Materials Science, Institute of Metal Research, Chinese Academy of Sciences, Shenyang 110016, Liaoning, China
}

\section{A R T I C L E I N F O}

\section{Article history:}

Received 30 November 2018

Accepted 4 December 2018

Published 5 February 2019

\section{Keywords:}

Mercury catalysts

Thermal stability

Defects

Oxygen groups

Acetylene hydrochlorination

\begin{abstract}
A B S T R A C T
Thermal stability of $\mathrm{HgCl}_{2}$ has a pivotal importance for the hydrochlorination reaction as the loss of mercuric compounds is toxic and detrimental to environment. Here we report a low-mercury catalyst which has durability over $10000 \mathrm{~h}$ for acetylene hydrochlorination under the industrial condition. The stability of the catalyst is carefully analyzed from a combined experimental and density functional theory study. The analysis shows that the extraordinary stability of mercury catalyst is resulted from the synergy effects between surface oxygen groups and defective edge sites. The binding energy of $\mathrm{HgCl}_{2}$ is increased to be higher than $130 \mathrm{~kJ} / \mathrm{mol}$ when adsorption is at the edge site with a nearby oxygen group. Therefore, the present study revealed that the thermal stability problem of mercury-based catalyst can be solved by simply adjusting the surface chemistry of activated carbon. Furthermore, the reported catalyst has already been successfully applied in the commercialized production of vinyl chloride.
\end{abstract}

(C) 2019, Dalian Institute of Chemical Physics, Chinese Academy of Sciences. Published by Elsevier B.V. All rights reserved.

\section{Introduction}

Vinyl chloride monomer (VCM) is a major chemical intermediate for the manufacture of polyvinyl chloride (PVC), which is the third most important polymer in use today [1,2]. At present, the VCM is generally synthesized by hydrochlorination of acetylene in regions of the world where coal is abundant, especially in China. However, production of VCM in acetylene hydrochlorination units consumes about 1400 tons mercury per annum before the low-mercury catalyst was applied, which caused big environmental problems. With the implementation of the mercury restriction, the solution of environment pollution problems involving mercury is one of the key technologies for vinyl chloride producing by calcium carbide method $[3,4]$. Although the gold based non-mercury catalyst invented by Hutchings' group shows superior performance and has been commercialized as mentioned in reference $[5,6]$. The wide application of the gold catalysts by the PVC enterprises still need much time due to its high cost. While other non-mercury catalyst like nitrogen doped catalysts are not active enough for application in industry [7-9]. Early in 2012, the Chinese government required the loading of $\mathrm{HgCl}_{2}$ to be reduced from 10

\footnotetext{
* Corresponding author. Tel: +86-571-88320766; Fax: +86-571-88320259; E-mail: liying@zjut.edu.cn

\# Corresponding author. Tel: +86-24-83970027; Fax: +86-24-23891320; E-mail: boli@imr.ac.cn

†These authors contributed equally to this work.

This work was supported by Qihe Investigation Company.

DOI: S1872-2067(19)63271-7 | http://www.sciencedirect.com/science/journal/18722067 | Chin. J. Catal., Vol. 40, No. 2, February 2019
} 
wt $\%-12$ wt $\%$ to $4 w t \%-6.5$ wt $\%$, which is called the low-mercury catalysts [10]. The fulfillment of the low-mercury catalyst in China has reduced more than $50 \%$ of the mercury consumption and the pollution of mercury has been greatly reduced in 2015. The low-mercury catalyst is still the major catalysts been used in the PVC factory nowadays before the mercury-free catalysts been mature and been widely applied. The stability of low-mercury catalysts should be different from the high-mercury catalyst due to the decreasing loading of $\mathrm{HgCl}_{2}$ to $4 \%-6.5 \%$ will results in a single layer dispersion of $\mathrm{HgCl}_{2}$ on carbon support [11]. However, the research work on the thermal stability of the low-mercury catalysts was neglected and rarely reported. The previous reports on the thermal stability of carbon supported mercury catalyst are mostly based on the high-mercury catalysts $[12,13]$. If the thermal stability is improved, the sublimation of $\mathrm{HgCl}_{2}$ will be suppressed and thus the environmental pollution can be greatly reduced since the catalysts will not be consumed during reaction.

At present, the strategies for the improvement of the stability for activated carbon (AC) supported mercury chloride ( $\left.\mathrm{HgCl}_{2} / \mathrm{AC}\right)$ catalysts mainly focus on two aspects: Firstly, alkali chloride was used as ligand as reported by Li et al. [14]. They observed that the thermal stability of the $\mathrm{HgCl}_{2} / \mathrm{AC}$ catalyst can be obviously improved when $\mathrm{CsCl}$ is co-impregnated with $\mathrm{HgCl}_{2}$ to AC support. Except for the addition of various promoters, there are also a few reports about the study on the carbon support. Wei et al. [15] and Xu et al. [16] studied on the coconuts based and coal based ACs including metal oxide supported low-mercury catalysts, but they didn't give a direct thermal stability test of catalysts and the mechanism study on the role of carbon surface chemistry. The identification of the role of surface functional groups on the supported metal catalysts such as $\mathrm{Ru}$ [17], Pt [18] and $\mathrm{Au}$ [19] etc. is receiving increasing interest in carbon materials research recently. It is clearly concluded that the interaction of supported active phase with the carbon supports plays an important role which will determine the dispersion and stability of active phases [20]. Several studies also indicated that defective sites are of great importance to the adsorption [21-23]. However, to our best knowledge there are no reports which have been devoted to understand the role of carbon-oxygen surface complexes or surface defects on the thermal stability of supported $\mathrm{HgCl}_{2}$ catalyst. The present work will concentrate on thermal stability of the low-mercury catalysts, the interaction of carbon surface functional groups and surface defects with $\mathrm{HgCl}_{2}$ molecular by experimental and theory calculations.

The texture and surface structure of carbon supports were fully characterized and discussions are given in supporting information (Figs. S1-S7, Tables S1-S4). The coal and wood based commercialized activated carbons were used for study which is denoted as AC-C and AC-W, respectively. AC-W700 was prepared by calcination of $\mathrm{AC}-\mathrm{W}$ under inert gas flow to remove the acidic functional groups. Briefly, all the activated carbons have a surface area higher than $1000 \mathrm{~m}^{2} / \mathrm{g}$ (Table 1), and the ash content is in range of $3.00 \%-3.25 \%$. The impurities are mainly silica and alumina oxide with very few amount of calcium oxide. The elemental analyses of activated carbons are provided in Table S2. The main difference between these activated carbons is the surface structures and oxygen contents. AC-W has abundant oxygen containing surface functional groups (SFGs), the oxygen content is as high as 33\% according to the CHNS elemental analysis. While the AC-W700 and AC-C has less SFGs, the oxygen content of AC-W700 is reduced to $16 \%$ and the oxygen content of AC-C is ca. $8 \%$. As demonstrated by X-ray diffraction (XRD), thermogravimetric (TG), and Raman characterizations, although the graphitic degree of AC-W700 and AC-C is better than that of the AC-W, the $I(\mathrm{D}) / I(\mathrm{G})$ value is higher for AC-W700 and AC-C than that of AC-W. This means that more surface defects are produced by the thermal treatment at $700{ }^{\circ} \mathrm{C}$. The AC-C has more surface defects than that of AC-W due to the less oxygen content. As reported by Lu et al. [21], graphene with rich surface defects can be obtained by using an oxidation step followed by a thermal decomposition method. As demonstrated by the TPD and FT-IR characterizations, AC-W contains much acidic functional groups such as carboxylic acids, phenols, and carboxylic anhydrides, while the AC-W700 and AC-C have more basic functional groups as lactones, ketone, and quinone which are more thermally stable.

The low-mercury catalysts were prepared by an incipient-wetness impregnation method. The isothermal curves and pore size distributions (Fig. S8) and XRD patterns (Fig. S9) of these catalysts are also similar to the ACs indicates a homogenous dispersion of the $\mathrm{HgCl}_{2}$ on the surface of ACs supports and no crystallite of $\mathrm{HgCl}_{2}$ exist in the catalyst. The texture properties of these catalysts are given in Table 1 . The decreasing of the surface area and pore volume of the catalysts compared with their corresponding ACs is small which indicates that the $\mathrm{HgCl}_{2}$ molecule is monodispersed in the pore of ACs.

Table 1

Texture properties and TG analysis data of various catalysts and supports.

\begin{tabular}{|c|c|c|c|c|c|c|c|}
\hline \multirow{2}{*}{ Samples } & \multirow{2}{*}{$\begin{array}{c}\text { S. A. } \\
\left(\mathrm{m}^{2} / \mathrm{g}\right)\end{array}$} & \multirow{2}{*}{$\begin{array}{c}\text { P. V. } \\
\left(\mathrm{cm}^{3} / \mathrm{g}\right)\end{array}$} & \multicolumn{3}{|c|}{ Mass loss (\%) a at different temperature range } & \multirow{2}{*}{ Temperature ${ }^{\mathrm{b}}\left({ }^{\circ} \mathrm{C}\right)$} & \multirow{2}{*}{$\mathrm{HgCl}_{2}(\mathrm{wt} \%)$} \\
\hline & & & $110-200^{\circ} \mathrm{C}$ & $200-500{ }^{\circ} \mathrm{C}$ & $500-850^{\circ} \mathrm{C}$ & & \\
\hline$\overline{\mathrm{AC}-\mathrm{W}}$ & 1364 & 0.92 & 0.6 & 5.4 & 13.7 & - & - \\
\hline AC-W700 & 1237 & 0.78 & 0.6 & 2.3 & 6.1 & - & - \\
\hline AC-C & 1150 & 0.78 & 0.4 & 1.3 & 2.8 & - & - \\
\hline $\mathrm{HgCl}_{2} / \mathrm{AC}-\mathrm{W}$ & 1152 & 0.80 & 0.6 & 12.7 & 7.5 & 302 & 6.3 \\
\hline $\mathrm{HgCl}_{2} / \mathrm{AC}-\mathrm{W} 700$ & 1180 & 0.75 & 0.4 & 9.2 & 5.6 & 360 & 6.4 \\
\hline $\mathrm{HgCl}_{2} / \mathrm{AC}-\mathrm{C}$ & 1139 & 0.57 & 0.3 & 7.8 & 5.4 & 382 & 6.4 \\
\hline
\end{tabular}

a The mass loss of different ACs and catalysts calculated based on TG analysis under argon flow.

${ }^{\mathrm{b}}$ The temperature of fast weight loss (assigned to the loss of $\mathrm{HgCl}_{2}$ on various catalysts). 
TG techniques were conducted under argon flow to evaluate the thermal stability of various low-mercury catalysts supported on the above ACs. TG and DTG profiles of the $\mathrm{HgCl}_{2}$ /AC-W, $\mathrm{HgCl}_{2}$ /AC-W700 and $\mathrm{HgCl}_{2}$ /AC-C catalysts are given in Fig. 1(a). For comparison, the TG and DTG profile of various ACs are also measured under same conditions, which are given in Fig. S10. The TG profile of $\mathrm{HgCl}_{2}$ is provided in Fig. $\mathrm{S} 11$, the sublimation temperature is as low as $140^{\circ} \mathrm{C}$. From Fig. 1 , it can be seen that the mass loss curves can be obviously divided into three temperature ranges. The mass loss occurs at ca. $100{ }^{\circ} \mathrm{C}$ is caused by the evaporation of physical adsorbed water. The amounts of water for all the samples are below $0.6 \%$ due to all the samples were dried before the TG experiments. The second mass loss occurs at $200-500{ }^{\circ} \mathrm{C}$, there are obvious DTG peaks for all the catalysts. The peak of DTG profiles for $\mathrm{HgCl}_{2}$ /AC-W, $\mathrm{HgCl}_{2}$ /AC-W700 and $\mathrm{HgCl}_{2}$ /AC-C catalysts are at 302,360 and $382{ }^{\circ} \mathrm{C}$, respectively. To eliminate the mass loss of the activated carbon, the subtracted data of the mass loss ratio at $200-500{ }^{\circ} \mathrm{C}$ of the catalysts and their related support are given in Table 1 . The weight loss is in the range of $6.5 \%-7.3 \%$, considering the experimental error, which is in the same level of the $\mathrm{HgCl}_{2}$ loading. This confirms the mass loss peak in this temperature range can be assigned to the sublimation of the adsorbed $\mathrm{HgCl}_{2}$ species. Since there is only one peak appears in TG curves for all the catalysts. It is in accord with the results characterized by the $\mathrm{N}_{2}$ sorption and XRD techniques.

It is interesting to note that the sublimation temperature of $\mathrm{HgCl}_{2}$ are all higher than the $200{ }^{\circ} \mathrm{C}$, and the maximum weight loss temperature of $\mathrm{HgCl}_{2}$ for $\mathrm{HgCl}_{2} / \mathrm{AC}-\mathrm{W}, \mathrm{HgCl}_{2} / \mathrm{AC}-\mathrm{W} 700$ and $\mathrm{HgCl}_{2} / \mathrm{AC}-\mathrm{C}$ are 302,360 and $382{ }^{\circ} \mathrm{C}$, respectively. The higher sublimation temperature of the $\mathrm{HgCl}_{2}$ indicates a stronger interaction of $\mathrm{HgCl}_{2}$ with carbon support. Moreover, the difference of the $\mathrm{HgCl}_{2}$ sublimation temperature for various catalysts and $\mathrm{HgCl}_{2}$ may indicate that the interaction of $\mathrm{HgCl}_{2}$ molecular with activated carbons is different and there are properly strong interaction between the $\mathrm{HgCl}_{2}$ and the carbon supports.
X-ray photoelectron spectroscopy (XPS) was used to characterize the status of $\mathrm{HgCl}_{2}$ on various catalysts. The high-resolution $\mathrm{Hg} 4 f$ spectra for $\mathrm{HgCl}_{2} / \mathrm{AC}-\mathrm{W}, \mathrm{HgCl}_{2}$ / $\mathrm{AC}-\mathrm{W} 700$ and $\mathrm{HgCl}_{2} / \mathrm{AC}-\mathrm{C}$ catalysts were given in Fig. 1(b). It can be seen that the photoelectron spectra of $\mathrm{Hg} 4 f$ clearly shows two doublet-peaks, the spin-orbit splitting of $\mathrm{Hg} 4 f$ was $4.1 \mathrm{eV}$ and intensity ratio was about $4: 3\left(\mathrm{Hg} 4 f_{7 / 2}: \mathrm{Hg} 4 f_{5 / 2}\right)$ [24]. For $\mathrm{HgCl}_{2} / \mathrm{AC}-\mathrm{W}$, the main peak of $\mathrm{Hg} 4 f_{7 / 2}$ at $101.4 \mathrm{eV}$, which is attributed to $\mathrm{Hg}^{2+}$ species and there are apparently no $\mathrm{Hg}^{+}$and $\mathrm{Hg}^{0}$ species [25-27]. For $\mathrm{HgCl}_{2} / \mathrm{AC}-\mathrm{W} 700$ and $\mathrm{HgCl}_{2} / \mathrm{AC}-\mathrm{C}$, the main peaks are shifted to $100.8 \mathrm{eV}$. The fitting of the peaks shows there are two species exist in these samples with around $65 \%$ of mercury was ascribed to $\mathrm{Hg}^{+}$species $(100.8 \mathrm{eV})$ and around $30 \%$ of mercury was ascribed to $\mathrm{Hg}^{2+}$ species $(101.4$ $\mathrm{eV})$.

From above analysis, it is clearly indicated that $\mathrm{HgCl}_{2}$ /AC-W700 and $\mathrm{HgCl}_{2}$ /AC-C catalysts are more stable than $\mathrm{HgCl}_{2} / \mathrm{AC}-\mathrm{W}$. To further understand the origin of the enhanced stability, DFT calculations are performed to study the interactions between $\mathrm{HgCl}_{2}$ molecule and carbon supports. One of the important differences between AC-W700, AC-C and AC-W is the oxygen group and surface defects as characterized by TPD and Raman techniques. The carboxylic and phenol groups are dominant on AC-W while AC-W700 and AC-C have more quinone and ketone groups. Therefore the binding energy of the $\mathrm{HgCl}_{2}$ molecule at the different oxygen groups are calculated including quinone, ketone, carboxyl, lactone and phenol groups (Fig. S12, Table S5). It is clearly indicated that the binding energy of $\mathrm{HgCl}_{2}$ is decreased along quinone, ketone, carboxyl, lactone and phenol groups. The quinone group is the most strong adsorption site for $\mathrm{HgCl}_{2}$ while the phenol group is the weakest site among the investigated oxygen groups. Not only oxygen groups on the support but also defective sites such as vacancy and edge are considered in the calculations. The binding energy of $\mathrm{HgCl}_{2}$ on defective site is indeed bigger than the strongest oxygen site (quinone) which are 49.20, 36.95 and $47.28 \mathrm{~kJ} / \mathrm{mol}$ at zigzag, armchair edges and mono-vacancy re-

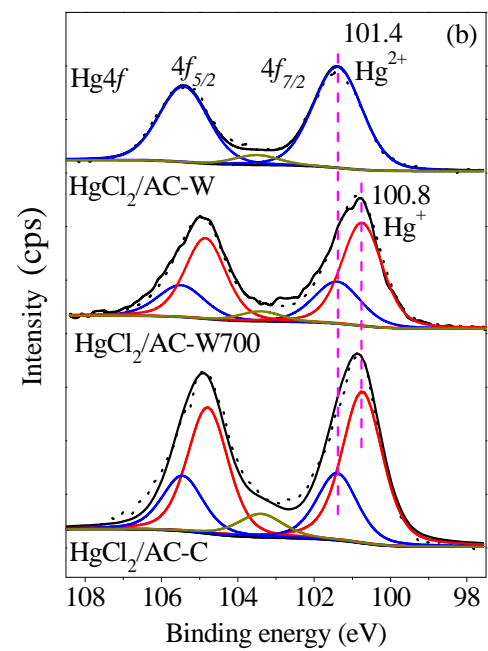

Fig. 1. (a) TG and DTG profiles and (b) $\mathrm{Hg} 4 f \mathrm{XPS}$ spectra for $\mathrm{HgCl}_{2} / \mathrm{AC}-\mathrm{W}, \mathrm{HgCl}_{2} / \mathrm{AC}-\mathrm{W} 700$ and $\mathrm{HgCl}_{2} / \mathrm{AC}-\mathrm{C}$ catalysts. 


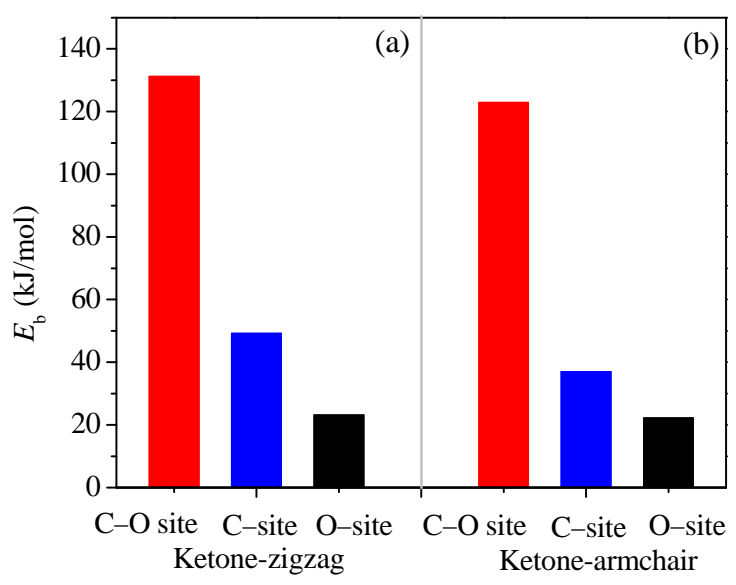

Fig. 2. The binding energy of $\mathrm{HgCl}_{2}$ at various sites. (a) The $E_{\mathrm{b}}$ of $\mathrm{HgCl}_{2}$ at Ketone zigzag; (b) The $E_{\mathrm{b}}$ of $\mathrm{HgCl}_{2}$ at Ketone armchair.

spectively. The increased binding energy at defective sites is resulted from the saturated dangling bond. However, the binging energy of $\mathrm{HgCl}_{2}$ at either oxygen site or edge site is still small and below $50 \mathrm{~kJ} / \mathrm{mol}$. Furthermore, the Mayer bond order of $\mathrm{Hg}-\mathrm{C}$ and $\mathrm{Hg}-\mathrm{O}$ is 0.37 and 0.2 respectively which indicate this is a weak intermolecular interaction. Interestingly, it is found the binding energy of $\mathrm{HgCl}_{2}$ is up to $130 \mathrm{~kJ} / \mathrm{mol}$ when adsorption takes place at the edge adjacent to a carbonyl group (ketone and quinone) as shown in Table S5. And the bond order is 0.64 . It is suggested that the adjacent oxygen greatly enhances the binding energy at the edge site. As shown in our previous work, the insertion of oxygen group can decrease the aromaticity of the carbon materials and increase the reactivity [28]. Based on these discussions, the DFT results are consistent with the experimental observations. The calculations indicate either carbonyl groups or the nearby carbon atom at edge are the most stable binding sites for $\mathrm{HgCl}_{2}$ molecule. This is well explained that the $\mathrm{HgCl}_{2}$ catalysts on the $\mathrm{AC}-\mathrm{C}$ and $\mathrm{AC}-\mathrm{W} 700$ have a better stability.

Stability of the catalysts is an important issue for their application in industry, especially for the supported mercuric

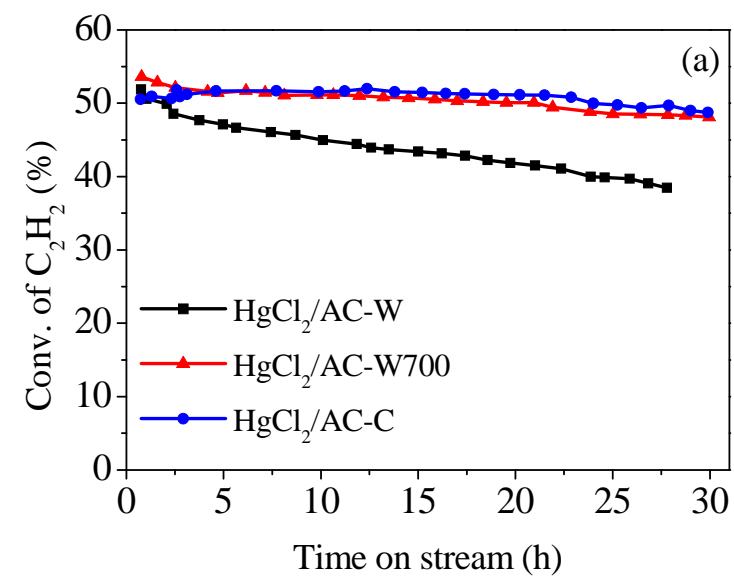

chloride catalysts. Because the loss of volatile mercury ultimately finds its way into the environment thus cause severe pollution of the environment [29]. The enthalpy of hydrochlorination of acetylene reaction is $-124.8 \mathrm{~kJ} / \mathrm{mol}$, which is strongly exothermic and it will generate a hotspot in the reactor which moves through the fixed bed reactor in the direction of the flow of the reactants [30]. The reaction temperature range in industry are controlled in a range of $80-180{ }^{\circ} \mathrm{C}$, the space velocity of total reaction gas in the range of $15-100 \mathrm{~h}^{-1}$ for a better control of temperature of reaction. In order to give a fast screen of the thermal stability of the catalysts, the reaction temperature and space velocity in our experiments was set at $180{ }^{\circ} \mathrm{C}$ and $1000 \mathrm{~h}^{-1}$. The time on stream catalytic performances of the above catalysts supported on various activated carbons $\left(\mathrm{HgCl}_{2} / \mathrm{AC}-\mathrm{W}, \mathrm{HgCl}_{2} / \mathrm{AC}-\mathrm{W} 700\right.$ and $\left.\mathrm{HgCl}_{2} / \mathrm{AC}-\mathrm{C}\right)$ in acetylene hydrochlorination are shown in Fig. 3(a). It can be seen that the initial activity is similar for all the three catalysts. But the deactivation rate of these three catalysts was evidently differed with the order of $\mathrm{HgCl}_{2} / \mathrm{AC}-\mathrm{W}>\mathrm{HgCl}_{2} / \mathrm{AC}-\mathrm{W} 700>$ $\mathrm{HgCl}_{2}$ /AC-C. This order is same with the thermal stability of these catalysts characterized above. Combining with the XPS results and catalytic performance, both $\mathrm{Hg}^{2+}$ and $\mathrm{Hg}^{+}$could be involved as center of catalysis in this reaction. This is similar with $\mathrm{Au}$ /carbon catalysts, as reported by Hutchings et al. the redox couple of $\mathrm{Au}^{+} / \mathrm{Au}^{3+}$ has been suggested to be the active center in VCM [6].

To further test the stability of the mercury catalyst, an experiment simulated the industrialized reaction condition has been done in lab. The conversion of acetylene and selectivity to vinyl chloride with reaction time is given in Fig. 3(b). The initial conversion of acetylene is about $96 \%$, after $10000 \mathrm{~h}$ running (ca. $417 \mathrm{~d}$ ) still as high as $88.6 \%$. This excellent catalytic performance confirmed that thermal stability is the key point to life time of mercury catalysts as demonstrated in reference by Hutchings group's early report $[12,13]$. According to TG characterization results, the initial evaporation of the most stable $\mathrm{HgCl}_{2}$ /AC-C catalyst is increased to above $300{ }^{\circ} \mathrm{C}$. There are almost $120{ }^{\circ} \mathrm{C}$ improved. The sublimation of $\mathrm{HgCl}_{2}$ will not occur under industry operation temperatures $\left(80-180{ }^{\circ} \mathrm{C}\right)$.

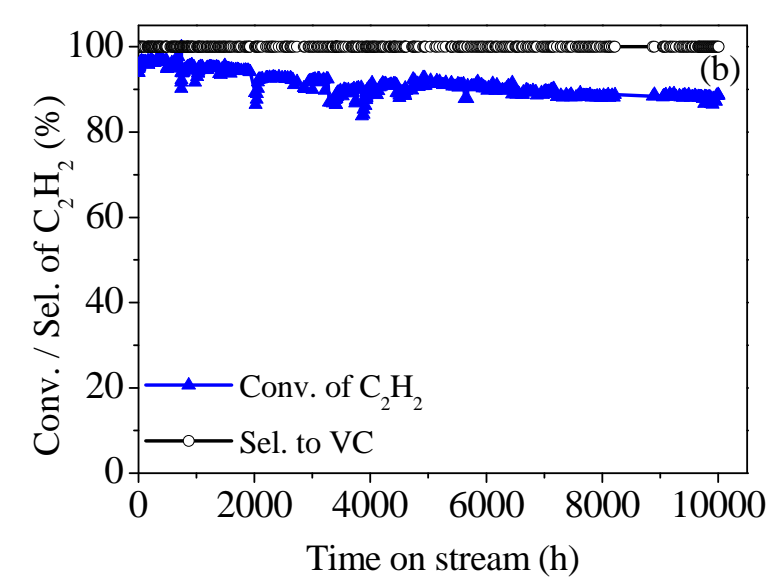

Fig. 3. (a) Acetylene conversion vs reaction time over various catalysts at reaction temperature $180{ }^{\circ} \mathrm{C}$ and $\mathrm{GHSV}\left(\mathrm{C}_{2} \mathrm{H}_{2}\right) 1000 \mathrm{~h}^{-1}$; (b) $\mathrm{Acetylene}$ conversion and selectivity to vinyl chloride vs reaction time over $\mathrm{HgCl}_{2} / \mathrm{AC}-\mathrm{C}$ catalysts at reaction temperature $140{ }^{\circ} \mathrm{C}$ and $\mathrm{GHSV}\left(\mathrm{C}_{2} \mathrm{H}_{2}\right) 30 \mathrm{~h}^{-1}$. 
Therefore, the leaching of $\mathrm{HgCl}_{2}$ for mercury catalysts used in industry caused by the thermally unstable properties can be greatly solved.

The thermal stability improvement of mercury related catalysts insures a long service life of mercury based catalysts under reaction conditions. This has significant impact on the elimination of the environmental pollution problems for mercury related catalytic process in industry. For example, commercial production of VCM (ca. 20 million tons PVC per annum in China is based on the acetylene based process) in acetylene hydrochlorination units consumes about 1000 tonnes Hg per annum. The fulfilment of the low-mercury catalysts for PVC production required the loading of $\mathrm{HgCl}_{2}$ decreased from 10 $w t \%-12 w t \%$ to $4 w t \%-6.5 w t \%$ has reduced the almost half of the mercury consumption. Therefore, the release of mercury chloride for the application of new generation low-mercury catalysts can be diminished to quite low level. This thermally stable low-mercury catalyst has already been successfully commercialized and applied in PVC factories. The environmental problems caused by thermally unstable mercury catalysts are greatly reduced. The combination of fundamental and experimental research proved essential for the successful development of this robust technology.

\section{Acknowledgments}

The authors thank Dr. Liang Wang in Zhejiang University for the Raman measurement and fruitful discussions with Professor Junling Lu in University of Science and Technology of China.

\section{References}

[1] H. Schobert, Chem. Rev., 2014, 114, 1743-1760.

[2] J. Liu, G. J. Lan, Y. Y. Qiu, X. L. Wang, Y. Li, Chin. J. Catal., 2018, 39,
1664-1671.

[3] T. Degnan, Focus on Catalysts, 2016, 3, 1-2.

[4] Y. Lin, S. X. Wang, Q. R. Wu, T. Larssen, Environ. Sci. Technol., 2016, $50,2337-2344$.

[5] P. Johnston, N. Carthey, G. J. Hutchings, J. Am. Chem. Soc., 2016, 137, 14548-14557.

[6] G. Malta, S. A. Kondrat, S. J. Freakley, C. J. Davies, L. Lu, S. Dawson, A. Thetford, E. K. Gibson, D. J. Morgan, W. Jones, P. P. Wells, P. Johnston, C. R. A. Catlow, C. J. Kiely, G. J. Hutchings, Science, 2017, 355, 1399-1403.

[7] X. Y. Li, X. L. Pan, L. Yu, P. J. Ren, X. Wu, L. T. Sun, F. Jiao, X. H. Bao, Nat. Commun., 2014, 5, 3688.

[8] G. J. Lan, Y. Wang, Y. Y. Qiu, X. L. Wang, J. Liang, W. F. Han, H. D. Tang, H. Z. Liu, J. Liu, Y. Li, Chem. Commun., 2018, 54, 623-626.

[9] Y. Yang, G. J. Lan, X. L. Wang, Y. Li, Chin. J. Catal., 2016, 37, 1242-1248.

[10] C. Liu, C. H. Liu, J. H. Peng, L. B. Zhang, S. X. Wang, A. Y. Ma, Chin. J. Chem. Eng., 2018, 26, 364-372.

[11] Y. C. Xie, Y. Q. Tang, Adv. Catal., 1990, 37, 1-43.

[12] G. J. Hutchings, D. T. Grady, Appl. Catal., 1985, 16, 411-415.

[13] G. J. Hutchings, J. Catal., 1985, 96, 292-295.

[14] X. L. Xu, J. Zhao, C. S. Lu, T. T. Zhang, X. X. Di, S. C. Gu, X. N. Li, Chin. Chem. Lett., 2016, 27, 822-826.

[15] X. B. Wei, H. B. Shi, W. Z. Qian, G. H. Luo, Y. Jin, F. Wei, Ind. Eng. Chem. Res., 2009, 48, 128-133.

[16] L. L. Xu, X. G. Wang, H. Y. Zhang, B. Dai, Z. Y. Liu, Q. F. Zhang, Chem. Ind. End. Prog., 2011, 30, 536-541.

[17] Y. Li, G. J. Lan, G. Q. Feng, J. Wei, W. F. Han, H. D. Tang, H. Z. Liu, ChemCatChem, 2014, 6, 572-579.

[18] X. M. Wang, N. Li, J. A. Webb, L. D. Pfefferle, G. L. Haller, Appl. Catal. $B, \mathbf{2 0 1 0}, 101,21-30$.

[19] J. H. Xu, J. Zhao, J. Xu, T. T. Zhang, X. N. Li, X. X. Di, J. Ni, J. G. Wang, C. Jie, Ind. Eng. Chem. Res., 2014, 53, 14272-14281.

[20] M. R. Axet, O. Dechy-Cabaret, J. Durand, M. Gouygou, P. Serp, Coord. Chem. Rev., 2016, 308, 236-345.

[21] H. Yan, H. Cheng, H. Yi, Y. Lin, T. Yao, C. L. Wang, J. J. Li, S. Q. Wei, J. L. Lu, J. Am. Chem. Soc., 2015, 137, 10484-10487.

\section{Graphical Abstract}

Chin. J. Catal., 2019, 40: 141-146 doi: S1872-2067(19)63271-7

The origin of the extraordinary stability of mercury catalysts on the carbon support: the synergy effects between oxygen groups and defects revealed from a combined experimental and DFT study

Jian Li, Jiangtao Fan, Sajjad Ali, Guojun Lan, Haodong Tang, Wenfeng Han, Huazhang Liu, Bo Li*, Ying Li* Zhejiang University of Technology; Institute of Metal Research, Chinese Academy of Sciences

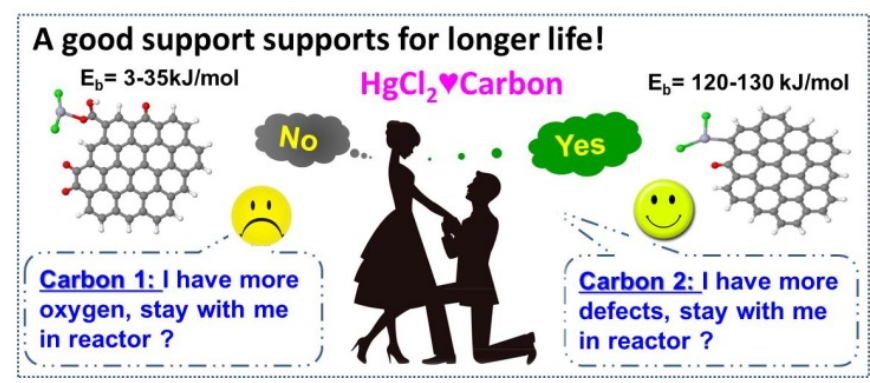

$\mathrm{HgCl}_{2}$ /carbon: Thermally unstable! Proper carbon support with more surface defects shows stronger $\mathrm{C}-\mathrm{HgCl}_{2}$ interaction, which greatly increases the thermal stability of mercury catalyst. 
[22] W. Y. Chen, J. Ji, S. Z. Duan, G. Qian, P. Li, X. G. Zhou, D, Chen, W. K. Yuan, Chem. Commun., 2014, 50, 2142-2144.

[23] W. Y. Chen, X. Z. Duan, G. Qian, D. Chen, X. G. Zhou, ChemSusChem, 2015, 8, 2927-2931.

[24] P. Behra, P. Bonnissel-Gissinger, M. Alnot, R. Revel, J. J. Ehrhardt, Langmuir, 2001, 17, 3970-3979.

[25] R. S. Vieira, M. L. M. Oliveira, E. Guibal, E. Rodríguez-Castellón, M. M. Beppu, Colloids Surf. A, 2011, 374, 108-114.

[26] Y. V. Fedoseeva, A. S. Orekhov, G. N. Chekhova, V. O. Koroteev, M. A.
Kanygin, B. V. Senkovskiy, A. Chuvilin, D. Pontiroli, M. Ricco, L. G. Bulusheva, A. V. Okotrub, ACS Nano, 2017, 11, 8643-8649.

[27] E. Sasmaz, A. Kirchofer, A. D. Jew, A. Saha, D. Abram, T. F. Jaramillo, J. Wilcox, Fuel, 2012, 99, 188-196.

[28] X. Y. Sun, B. Li, D. S. Su, Chem. Asian J., 2016, 11, 1668-1671.

[29] W. Ren, L. Duan, Z. W. Zhu, W. Du, Z. Y. An, L. J. Xu, C. Zhang, Y. Q. Zhuo, C. H. Chen, Environ. Sci. Technol., 2014, 48, 2321-2327.

[30] M. Y. Zhu, Q. Q. Wang, K. Chen, Y. Wang, C. F. Huang, H. Dai, F. Yu, L. H. kang, B. Dai, ACS Catal., 2015, 5, 5306-5316.

\title{
超稳低录催化剂的稳定机理：炭表面含氧基团及缺陷协同作用实验及理论研究
}

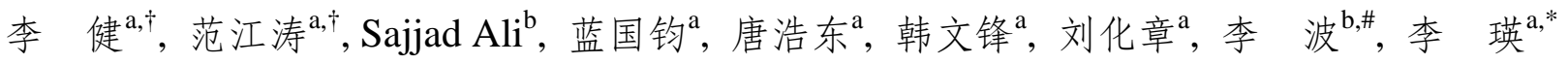 \\ a浙江工业大学工业催化研究所, 浙江杭州 310014 \\ b 中国科学院金属研究所, 辽宁沈阳 110016
}

\begin{abstract}
摘要: 聚氯乙烯(PVC)作为五大工程塑料之首在材料领域应用广泛. 2017年, 中国PVC产能逾2600万吨, 占世界总产量的 $70 \%$ 以上, PVC产业是我国重要支柱产业之一. 基于中国富煤少气缺油的能源格局, PVC产量的 $90 \%$ 以上都是基于煤化工 的乙炔法生产的, 而氯化录催化剂是目前乙炔法氯乙烯工业上唯一实现产业化应用的催化剂. 但是由于氯化录属于金属 氯化物中唯一的共价化合物, 其热稳定极差, 涉录催化剂的录污染问题一直是氯乙烯行业的世界级难题. 中国电石法聚氯 乙烯产业每年催化剂消耗量高达 2.0 万吨, 年耗永近 1000 吨, 可回收不足 $40 \%$, 占世界录消耗量的 $70 \%$. 而无录催化剂由于成 本高、使用寿命短等原因, 短期内实现工业化应用及推广仍有困难. 中国政府早在2014年开始限录行动, 提出了氯乙烯产 业录催化剂减量化直至无录化的战略目标. 根据2015年拟定的氯乙烯用低录触媒的国标要求, 氯化录负载量最高不得超 过6.5\%, 而高录催化剂的氯化录负载量在 $10 \%-12 \%$ 之间, 在氯化录负载量降低一半的情况下保持催化剂的高性能及高热 稳定性对催化剂的制备技术提出了很大的挑战. 催化剂是参与化学反应而自身不会消耗的物质, 其在工业使用过程中理 论上并不会消耗, 解决了催化剂的热稳定性问题, 不但可以延长催化剂使用寿命, 而且还可以缓解涉录催化剂的资源消耗 及环境污染问题.

活性炭具有较高的比表面积、可调控的表面化学性质和耐酸碱腐蚀性, 在工业中应用广泛. 氯乙烯单体合成的原料为 氯化氢和乙炔, 由于氯化氢的腐蚀性, 活性炭基催化剂在工业化应用方面具有明显的优势. 而活性炭载体的表面性质调控 及对负载型金属催化剂的相互作用研究一直是近年来多相催化领域的一个热点. 本文通过热处理的方法调控了活性炭的 表面含氧基团, 研究了活性炭的表面结构的区别, 通过浸渍法制备了三种活性炭负载的低录催化剂, 对比了三种不同的活 性炭载体的乙炔氢氯化性能及稳定性, 发现表面基团的调控对低录催化剂的稳定性具有较大的影响. 热重实验表明, $\mathrm{HgCl}_{2} / \mathrm{AC}$-C 催化剂中氯化录的最大失重温度提高到了 $380^{\circ} \mathrm{C}$ 以上. 该催化剂在反应温度 $140{ }^{\circ} \mathrm{C}$, 乙炔空速 $30 \mathrm{~h}^{-1}$ 条件下稳 定运行 $10000 \mathrm{~h}$, 乙炔转化率只下降了 $8 \%$. DFT理论计算发现, 碳氧双键旁边的缺陷位和氯化录可以形成强的化学吸附, 其 吸附能可达120-130 kJ/mol, 而氯化录在含氧基团的表面吸附能只有3-35 kJ/mol. 本文通过对活性炭表面结构的调控, 使氯 化录和炭表面活性位形成化学吸附, 可大大提高催化剂的耐热稳定性, 从理论上给出了低录催化剂的热稳定性解决方案, 目前该催化剂已经成功实现了产业化应用, 在工业转化器上使用寿命超过 $12000 \mathrm{~h}$, 性能表现卓越. 超稳低录催化剂的工业 化应用不仅能够降低氯乙烯单体生产过程中的单耗, 节约PVC生产成本, 还能够有效减少录触媒使用过程中造成的重金属 污染, 为我国电石法氯碱行业的节能减排及限录公约履约提供了很好的技术支撑和保障.
\end{abstract}

关键词: 录催化剂; 热稳定性; 缺陷; 含氧官能团; 乙炔氢氯化

收稿日期: 2018-11-30. 接受日期: 2018-12-04. 出版日期: 2019-02-05.

*通讯联系人. 电话: (0571)88320766; 传真: (0571)88320259; 电子信箱: liying@zjut.edu.cn

\#通讯联系人. 电话: (024)83970027; 传真: (024)23891320; 电子信箱: boli@imr.ac.cn

本文的电子版全文由Elsevier出版社在ScienceDirect上出版(http://www.sciencedirect.com/science/journal/18722067). 